Original Article

\title{
Karakteristik Fisiko - Kimia Dan Sensori Minyak Goreng Sawit Aromatik Terinfusi Kulit Batang Pohon Kulim (Scorodocarpus Bornensis)
}

\section{Physico-Chemical and Sensory Characteristics of Aromatic Palm Cooking Oil Infused with the Bark of the Kulim Tree (Scorodocarpus Bornensis)}

\author{
Dzul Fadly*, Yohana S. K. Dewi \\ Program Studi Teknologi Pangan, Universitas Tanjungpura, Pontianak, Indonesia
}

(*dzul.fadly@faperta.untan.ac.id)

\begin{abstract}
ABSTRAK
Pohon kulim (Scorodocarpus borneensis Becc.) atau dikenal dengan pohon bawang hutan adalah tanaman indigenous Kalimantan atau Borneo yang memiliki aroma bawang putih. Bagian-bagian tananaman ini berpotensi untuk dikembangkan sebagai bahan baku pembuatan minyak aromatik. Penelitian ini bertujuan untuk mengidentifikasi karakteristik fisiko-kimia, serta tingkat penerimaan sensori minyak goreng sawit aromatik yang dikembangkan dari minyak sawit goreng yang terinfusi kulit pohon kulim. Penelitian ini menggunakan Rancangan Acak Lengkap dengan 6 konsentrasi kulit pohon kulim. Preparasi minyak aromatik dilakukan dengan metode infusi kulit pohon kulim, dengan konsentrasi $1 \%, 2 \%, 3 \%, 4 \%, 5 \%$, dan $6 \%$ terhadap minyak goreng sawit. Sediaan minyak goreng sawit aromatik memiliki kandungan asam lemak berkisar antara $0,063 \pm 0,015 \%$ hingga $0,100 \pm 0,008 \%$ dan bilangan peroksida berkisar antara $6,05 \pm 0,56 \%$ hingga $7,02 \pm 0,42 \%$. Nilai asam lemak dan bilangan peroksida cenderung menurun dengan adanya peningkatan kulit batang pohon kulim. Penambahan kulit pohon kulim dengan konsentrasi 1-6 \% memiliki nilai viskositas berkisar antara 58,3-69,9 Cp. Pada parameter penerimaan sensori, penambahan kulit batang pohon kulim mengakibatkan adanya peningkatan penerimaan aroma, namun menurunkan penerimaan warna dibandingkan dengan minyak sawit goreng nonaromatik. Dengan demikian, maka kulit batang pohon kulim berpotensi sebagai bahan pembuatan minyak aromatik.
\end{abstract}

Kata kunci : Scorodocarpus borneensis Becc., kulit batang, minyak aromatik, asam lemak bebas, bilangan peroksida

\section{ABSTRACT}

The kulim tree (Scorodocarpus borneensis Becc.) or known as the forest onion tree is an indigenous plant of Kalimantan or Borneo that produces a garlic aroma. These plant parts have the potential to be developed as raw materials for the manufacture of aromatic oils. This study aimed to identify the physico-chemical characteristics, as well as the level of sensory acceptance of aromatic palm cooking oil developed from cooking palm oil infused with the bark of the kulim tree. This study used a completely randomized design with 6 concentrations of kulim bark. Aromatic oil preparation was carried out using the kulim tree bark infusion method, with concentrations of 1\%, 2\%, 3\%, 4\%, 5\%, and $6 \%$ toward palm cooking oil. Aromatic palm cooking oil contains fatty acids ranging from $0.063 \pm 0.015 \%$ to $0.100 \pm 0.008 \%$ and peroxide values ranging from $6.05 \pm 0.56 \%$ to $7.02 \pm 0.42 \%$. The value of fatty acids and peroxide values tended to decrease with the increase in the kulim bark. The addition of kulim bark with a concentration of 1-6\% has a viscosity value ranging from 58.3-69.9 Cp. According to the sensory acceptance parameter, the addition of the kulim bark results in an increase in aroma acceptance, but decreased color acceptance compared to non-aromatic cooking palm oil. Thus, the bark of the kulim tree is a potential ingredient for making aromatic oil.

Keywords : Scorodocarpus borneensis Becc., bark, aromatic oil, free fatty acids, peroxide value https://doi.org/10.33860/jik.v15i2.492 


\section{PENDAHULUAN}

Pemanfaatan minyak kelapa sawit dalam kehidupan semakin luas dan berkembang, baik sebagai bahan pangan, bahan baku kosmetik, hingga campuran bahan bakar ${ }^{(1)}$. Sebagai bahan pangan, minyak sawit diolah menjadi minyak goreng agar yang kemudian dimanfaatkan sebagai penunjang dalam pengolahan makanan, terutama proses penggorengan. Selain itu, minyak sawit diolah menjadi kondimen bumbu pelengkap, berupa minyak bumbu aromatik yang dapat meningkatkan nilai sensori makanan olahan. Minyak bumbu aromatik yang saat ini telah banyak dikomersilkan adalah minyak cabe dan minyak bawang putih.

Minyak aromatik disiapkan dengan melakukan proses infusi bahan terhadap minyak $^{(2)}$. Bahan baku yang digunakan sebagai infus minyak umumnya adalah material bumbu masakan dengan aroma menyengat. Salah satu material yang dapat digunakan sebagai bumbu masakan tradisional dengan aroma menyerupai bawang adalah pohon kulim. Pohon kulim (Scorodocarpus borneensis Becc.) atau dikenal dengan pohon bawang hutan adalah tanaman indigenous Kalimantan atau Borneo ${ }^{(11)}$.

Tanaman ini sejak lama dimanfaatkan sebagai bumbu masakan karena aroma yang menyerupai bawang putih, baik buah, daun, maupun kulit batang. Suku dayak menggunakan kulim sebagai rempah pengganti bawang putih, selain ditujukan sebagai pengawet alami daging dan minyak goreng agar tidak mudah teroksidasi ${ }^{(3)}$. Aroma pada pohon kulim berasal dari senyawa aromatik metil tiometil sulfida yang memberikan efek aroma bawang putih ${ }^{(4)}$. Dengan demikian maka bagian-bagian tananaman ini berpotensi untuk dikembangkan sebagai bahan baku minyak aromatik.

Penelitian ini bertujuan untuk mengidentifikasi karakteristik fisiko-kimia, serta tingkat penerimaan sensori minyak aromatik yang dikembangkan dari minyak sawit goreng yang terinfusi kulit pohon kulim.

\section{METODE PENELITIAN}

Penelitian ini dilaksanakan di Laboratorium Kimia Pangan dan Laboratorium Desain Pangan, Fakultas Pertanian, Universitas Tanjungpura, Pontianak. Bahan utama yang digunakan adalah kulit batang pohon kulim yang diperoleh dari Kabupaten Sanggau, Kalimantan Barat dan minyak goreng sawit komersial merek Bimoli. Penelitian ini menggunakan Rancangan Acak Lengkap dengan 6 konsentrasi kulit pohon kulim.

\section{Preparasi Minyak Aromatik}

Preparasi minyak aromatik dilakukan dengan metode infusi. Kulit pohon kulim yang telah disiapkan, dalam bentuk bubuk dimasukkan ke dalam minyak goreng sawit.

Kulit pohon kulim dibersihkan dan dikeringkan dibawah sinar matahari. Kulit pohon yang kering kemudian dihancurkan hingga halus dan diayak dengan ayakan 80 mesh untuk memperoleh bubuk kulit pohon. Bubuk tersebut kemudian dikeringkan menggunakan cabinet dryer pada suhu $50{ }^{\circ} \mathrm{C}$ selama 24 jam untuk menurunkan kadar air hingga $<10 \%{ }^{(2)}$. Selanjutnya, bubuk kulit pohon siap digunakan untuk proses infusi.

Proses infusi dilakukan terhadap minyak goreng sawit komersial. Sebanyak $200 \mathrm{ml}$ minya dimasukkan dalam botol berkapasitas $200 \mathrm{~mL}$, dan dipanaskan hingga mencapai suhu $80{ }^{\circ} \mathrm{C}$ menggunakan waterbath shaker. Kemudian, bubuk kulit pohon ditambahkan kedalam minyak tersebut, ditutup rapat, dan tetap dipanaskan pada suhu $80{ }^{\circ} \mathrm{C}$ selama 10 menit. Selanjutnya minyak diinkubasi pada suhu ruang selama 24 jam. Konsentrasi kulit pohon yang ditambahkan adalah $1 \%, 2 \%, 3 \%$, $4 \%, 5 \%$, dan $6 \%$ terhadap minyak goreng sawit. Minyak goreng sawit aromatik kemudian dianalisis properti fisiko-kimia dan penerimaan sensorinya.

\section{Analisis Kimia \\ Asam lemak bebas}

Sebanyak 5 g minyak goreng sawit aromatik ditimbang dalam iodine flask, dan ditambahkan $25 \mathrm{~mL}$ alkohol 96\%. Kemudian iodine flask tersebut dipanaskan menggunakan water bath shaker selama 10 menit, dimana larutan minyak didalamnya mendidih.larutan kemudian didinginkan dan ditambahkan dua tetes indikator phenolphtalein. Kemudian dilakukan titrasi dengan $\mathrm{NaOH} 0,01 \mathrm{~N}$ hingga berwarna merah jambu ${ }^{(5)}$. Kadar lemak bebas dihitung dengan persamaan:

$$
\% \text { FFA }=\frac{m L \mathrm{NaOH} \times \mathrm{N} \mathrm{NaOH} \times \mathrm{BM} \mathrm{NaOH}}{\text { Berat sampel }(\mathrm{g}) \times 1000} \times \frac{280}{B M \mathrm{NaOH}} \times 100 \%
$$

\section{Bilangan peroksida}

Sebanyak 2,5 g sampel minyak sawit goreng aromatik ditambahkan dengan $15 \mathrm{~mL}$ campuran asam asetat dan kloroform (rasio 3:2), kemudian dikocok hingga larut. Kemudian 
ditambahkan larutan $0,5 \mathrm{~mL}$ KI jenuh kedalam campuran, didiamkan selama 1 menit sambil sesekali dikocok, dan ditambahkan $15 \mathrm{~mL}$ akuades. Larutan tersebut kemudian dititrasi dengan $0,01 \mathrm{~N} \mathrm{Na}_{2} \mathrm{~S}_{2} \mathrm{O}_{3}$ hingga warna kuning hilang. Sebanyak $0,5 \mathrm{~mL}$ Larutan amilum $1 \%$ ditambahkan pada larutan dan kemudian titrasi hingga warna biru menghilang. Bilangan peroksida ditung dengan persamaan:

Bilangan peroksida $=\frac{m L ~ N a_{2} \mathrm{~S}_{2} \mathrm{O}_{3} \times \mathrm{N} \mathrm{Na}_{2} \mathrm{~S}_{2} \mathrm{O}_{3} \times 1000}{\text { Berat sampel }(\mathrm{g})}$

\section{Analisis Fisik}

Analisis fisik dilakukan terhadap viskositas minyak goreng sawit aromatik. Viskositas menyatakan nilai reologi cairan pada Viscometer Brookfield menggunakan spindel yang sesuai dengan keketalan cairan.

\section{Analisis Penerimaan Sensori}

Analisis penerimaan sensori dilakukan menggunakan uji ranking terhadap parameter warna dan $\operatorname{aroma}^{(6)}$. Respon panelis diekspresikan dalam bentuk skor $1-6$. Skor 1 memperlihatkan tingkat kesukaan pertaman, dan selanjutnya hingga skor 6 yang memperlihatkan tingkat kesukaan terakhir.

\section{Analisis Data}

Pengolahan data menggunakan software IBM SPSS Versi 23, dengan uji one way anova pada taraf $\alpha=0,05$, apabila berpengaruh nyata dilanjutkan dengan uji Duncan Multiple Range test.

\section{HASIL}

Hasil determinasi nilai asam lemak bebas (Free Fatty Acid (FFA)) dan bilangan peroksida pada tujuh formulasi sediaan minyak aromatik disajikan pada Tabel 1. Viskositas sediaan minyak aromatik dapat dilihat pada Gambar 1. Kemudian, nilai penerimaan sensori sediaan minyak aromatik disajikan pada Tabel 2.

Tabel 1. Nilai asam lemak bebas $(F F A)$ dan bilangan peroksida minyak aromatik terinfusi kulit pohon kulim

\begin{tabular}{|c|c|c|c|}
\hline \multirow{2}{*}{$\begin{array}{l}\text { Konsentrasi } \\
\text { Kulim (\%) }\end{array}$} & \multirow[t]{2}{*}{ 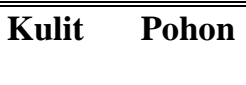 } & \multicolumn{2}{|l|}{ Parameter } \\
\hline & & Asam Lemak Bebas (\%) & Bilangan Peroksida (\%) \\
\hline 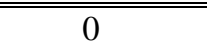 & & $0,105 \pm 0,005^{\mathrm{c}}$ & $8,8,13 \pm 0,51^{\mathrm{c}}$ \\
\hline 1 & & $0,091 \pm 0,015^{\mathrm{bc}}$ & $7,02 \pm 0,42^{\mathrm{b}}$ \\
\hline 2 & & $0,091 \pm 0,004^{\mathrm{bc}}$ & $6,85 \pm 0,61^{\mathrm{ab}}$ \\
\hline 3 & & $0,065 \pm 0,009^{\mathrm{a}}$ & $6,46 \pm 0,26^{\mathrm{ab}}$ \\
\hline 4 & & $0,063 \pm 0,015^{\mathrm{a}}$ & $6,41 \pm 0,33^{\mathrm{ab}}$ \\
\hline 5 & & $0,100 \pm 0,008^{\mathrm{c}}$ & $6,50 \pm 0,64^{\mathrm{ab}}$ \\
\hline 6 & & $0,082 \pm 0,014^{\mathrm{b}}$ & $6,05 \pm 0,56^{\mathrm{a}}$ \\
\hline P-value* & & $\overline{0,000}$ & $\overline{0,000}$ \\
\hline
\end{tabular}

*signifikan pada $\alpha=0,05$, berdasarkan uji T-test

Nilai asam lemak sediaan minyak aromatik ini cenderung berkisar antara $0,063 \pm 0,015 \%-$ $0,100 \pm 0,008 \%$. Pada sediaan minyak aromatik dengan konsentrasi kulit pohon kulim 1\%, 2\%, dan $5 \%$ memiliki nilai asam lemak bebas (secara berurutan yaitu $0,091 \pm 0,015 \%$, $0,091 \pm 0,004 \%$, dan $0,100 \pm 0,008 \%$ ) yang tidak berbeda signifikan terhadap nilai asam lemak bebas sediaan minyak nonaromatik kontrol dengan konsentrasi $0 \%$ kulit pohon kulim $(0,105 \pm 0,005 \%)$. Namun demikian, asam lemak bebas pada sediaan minyak nonaromatik kontrol berbeda signifikan terhadap sediaan minyak aromatik dengan konsentrasi kulit pohon kulim 3\%, 4\%, dan 6\% (secara berurutan yaitu $0,065 \pm 0,009 \%, \quad 0,063 \pm 0,015 \%$, dan $0,082 \pm 0,014 \%$ ) pada $\mathrm{P}<0,05$. Nilai asam lemak terkecil diketahui adalah pada formulasi sediaan minyak aromatik dengan konsentrasi kulit batang senilai $4 \%$ dan tertinggi adalah pada konsentrasi kulit pohon kulim senilai $5 \%$.

Bilangan peroksida sediaan minyak aromatik berkisar antara $6,05 \pm 0,56 \%$ $7,02 \pm 0,42 \%$, dan berbeda signifikan terhadap bilangan peroksida sediaan minyak nonaromatik kontrol ( $0 \%$ kulit pohon kulim) pada $\mathrm{P}<0,05$. Dengan penambahan kulit pohon kulim, semakin tinggi konsentrasi kulit pohon yang ditambahkan maka nilai bilangan peroksida cenderung menurun. Minyak nonaromatik $0 \%$ kulit batang memiliki bilangan peroksida $8,13 \pm 0,51 \%$. Nilai bilangan peroksida tertinggi adalah pada sediaan minyak aromatik dengan konsentrasi $1 \%$ kulit pohon 
yaitu senilai $7,02 \pm 0,42 \%$ dan terendah adalah pada sediaan minyak dengan konsentrasi $6 \%$ kulit pohon yaitu $6,05 \pm 0,56 \%$.

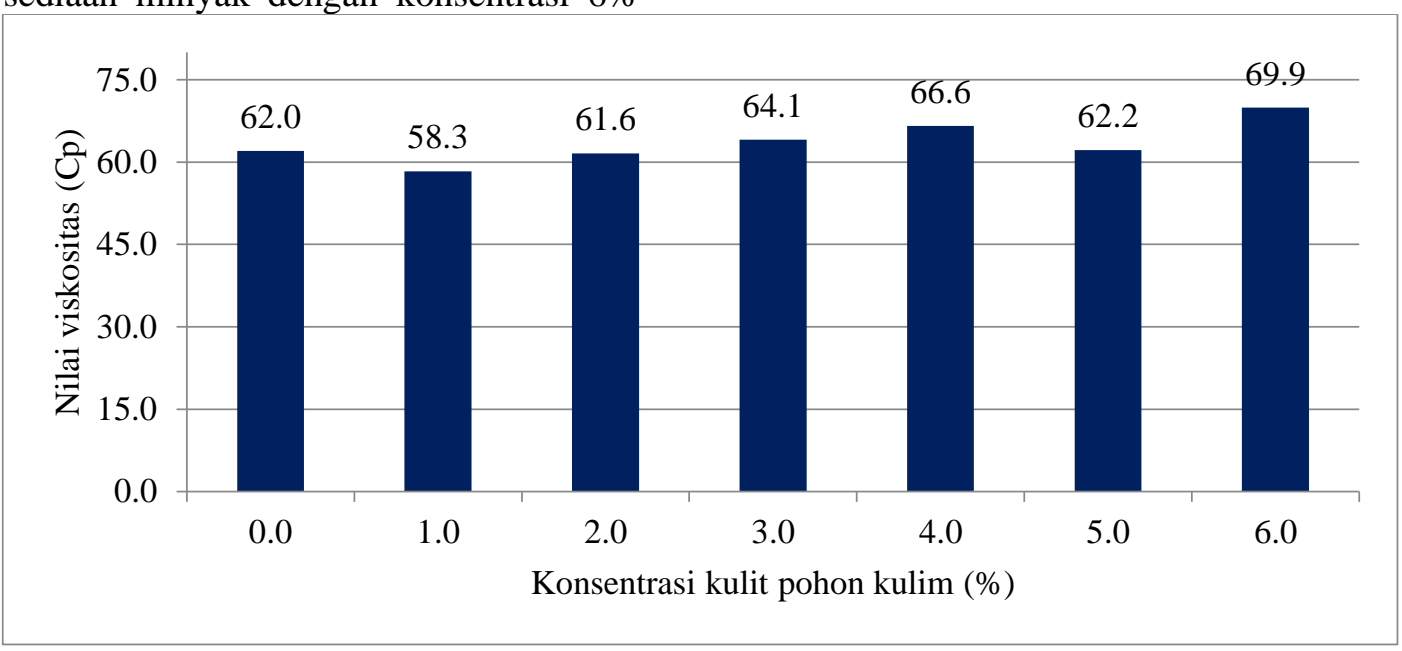

Gambar 1. Diagram viskositas sediaan minyak aromatik terinfusi kulit pohon kulim

Penambahan kulit pohon kulim dengan konsentrasi 1-6\% berkisar antara 58,3-69,9 Cp. Nilai viskositas pada sediaan minyak aromatik terendah dimiliki oleh sediaan minyak aromatik dengan konsentrasi $1 \%$ kulit pohon yaitu 58,3 $\mathrm{Cp}$ dan tertinggi dimiliki oleh sediaan minyak aromatik dengan konsentrasi $6 \%$ kulit pohon, yaitu 69,9 Cp. Namun, sediaan minyak nonaromatik kontrol (0\% konsentrasi kulit pohon kulim) memiliki nilai viskositas yaitu 6,2 Cp.

Tabel 2. Nilai penerimaan sensori sediaan minyak aromatik terinfusi kulit pohon kulim

\begin{tabular}{cll}
\hline \hline \multirow{2}{*}{\begin{tabular}{l} 
Konsentrasi Kulit Pohon Kulim \\
\cline { 2 - 3 }
\end{tabular}} & \multicolumn{1}{l}{ Parameter* } \\
\hline 0 & Aroma & Warna \\
\hline \hline 1 & $1,00 \pm 0,00$ & $6,00 \pm 0,00$ \\
\hline 2 & $2,63 \pm 1,06$ & $5,63 \pm 0,74$ \\
\hline 3 & $3,25 \pm 1,58$ & $4,63 \pm 1,30$ \\
\hline 4 & $4,63 \pm 1,30$ & $4,38 \pm 1,41$ \\
\hline 5 & $3,38 \pm 0,92$ & $4,50 \pm 0,53$ \\
\hline 6 & $3,75 \pm 1,04$ & $4,13 \pm 0,83$ \\
\hline \hline
\end{tabular}

*Uji ranking $1-6$.

Pada parameter aroma, penambahan kulit pohon kulim meningkatkan nilai sensory aroma sediaan minyak aromatik. Penambahan $1 \%$ kulit pohon kulim memiliki nilai terendah yaitu $2,63 \pm 1,06$ dan nilai tertinggi adalah pada penambahan $3 \%$ konsentrasi kulit pohon kulim, yaitu $4,63 \pm 1,30$. Sedangkan sediaan minyak nonaromatik control $(0 \%$ konsentrasi kulit pohon kulim) memiliki nilai nilai sensory aroma lebih rendah dari sediaan minyak aromatik, yaitu $1,00 \pm 0,00$.

\section{PEMBAHASAN}

\section{Sediaan Minyak Aromatik}

Sediaan minyak goreng sawit aromatik beraroma bawang putih pada penelitian ini merupakan formulasi minyak sawit dengan penambahan bahan aromatic berupa kulit pohon bawang hutan atau kulim (Scorodocarpus borneensis Becc). Penelitian ini mengkaji beberapa factor determinasi, seperti kandungan asam lemak bebas, bilangan peroksida, karakteristik sensori, dan katrakteristik fisik. Terdapat tujuh formulasi sediaan minyak aromatik, yaitu enam sediaan minyak goreng sawit dengan penambahan kulit pohon kulim $(1 \%, 2 \%, 3 \%$. 4\%, 5\%, dan 6\%) dan satu sediaan minyak goreng sawit nonaromatik tanpa adanya penambahan kulit pohon kulim sebagai kontrol (0\%). Sediaan minyak aromatik ini dipersiapkan dengan mengacu pada ${ }^{(2)}$. Penyiapan ini dilakukan dengan menambahkan 
sejumlah bubuk kulit pohon kulim dengan konsentrasi yang berbeda kemudian dipanaskan selama 10 menit menggunakan waterbath dengan suhu $80{ }^{\circ} \mathrm{C}$ selanjutnya diinkubasi tertutup pada suhu ruang selama 48 jam.

\section{Karakteristik Kimia}

Nilai asam lemak bebas dan peroksida ini juga merupakan komponen penentu tingkat kerusakan lemak ${ }^{(7)}$. Perbedaan bilangan peroksida yang signifikan antara sediaan minyak nonaromatik kontrol dan minyak aromatik dengan infusi kulit pohon kulim ini selaras dengan nilai asam lemak bebas yang juga berbeda signifikan antara minyak nonaromatik dan nonaromatik. Keduanya memperlihatkan bahwa peningkatan kandungan asam lemak akan cenderung meningkatkan bilangan peroksida. Hal ini disebabkan oleh gugus karboksilik asam lemak yang merupakan senyawa prooksidan yang mampu memproduksi komponen volatile penyebab bau tengik melalui oksidasi ${ }^{(8)}$.

Nilai asam lemak bebas dan bilangan peroksida menggambarkan tingkat kerusakan lemak oleh proses oksidasi ketengikan. Proses oksidasi pada lemak ini akan memotong ikatan ganda pada molekul trigliserida ${ }^{(9)}$. Pada awalnya, asam lemak bebas akan dirusak oleh molekul oksigen dengan bantuan cahaya atau panas $^{(10)}$. Selain dipengaruhi oleh senyawa prooksidan, bilangan peroksida juga dipengaruhi oleh adanya senyawa antioksidan. Berdasarkan ${ }^{(11)}$, kulit pohon kulim diketahui memiliki nilai total fenol $71,93 \mathrm{mg}$ Galat/ $\mathrm{g}$ ekstrak dan aktivitas antioksidan senilai 86,30 $\%$ tiap 400 ppm. Demikian, penambahan kulit pohon kulim telah berkontribusi pada penambahan antioksidan pada sediaan minyak aromatik. Hal ini terbukti dari adanya nilai asam lemak bebas dan bilangan peroksida yang signifikan lebih tinggi pada minyak nonaromatik kontrol dan lebih rendah pada sediaan minyak aromatik yang terinfusi kulit pohon kulim setelah melewati proses inkubasi tertutup pada suhu ruang selama 48 jam. Ini selaras dengan hasil penelitian yang dilakukan oleh Kiyomi dan Yasuko (1995), dan Yanping et al. (1999) yang memperlihatkan bahwa peroksida lemak akan mengalami penurunan yang signifikan dengan adanya penambahan antioksidan baik pada makanan ataupun minyak ${ }^{(12,13)}$

Proses pemanasan yang dilakukan pada tahap penyiapan sediaan minyak pada suhu 80 ${ }^{\circ} \mathrm{C}$ selama 10 menit diduga tidak merusak aktivitas antioksidan kulit pohon kulim secara menyeluruh. Oleh karena itu, antioksidan dari pohon kulim dapat berperan dalam proses penghambatan produksi asam lemak bebas dan bilangan peroksida pada sediaan lemak. Hasil yang sama ditemukan pada penelitian yang dilakukan oleh Rehman et al. (2003) pada sediaan minyak dengan penambahan ekstrak jahe. Pemanasan pada suhu mencapai $185{ }^{\circ} \mathrm{C}$ selama 20 atau 30 menit tidak menurunkan potensi antioksidan ekstrak jahe secara signifikan dan aktivitas antioksidan menurun perlahan akibat pemanasan selama 40 menit atau lebih lama ${ }^{(7)}$. Diduga pemanasan tersebut mengakibatkan evaporasi serta dekomposisi kimia pada ekstrak yang ditambahkan.

\section{Karakteristik Fisik}

Karakteristik fisik yang diamati adalah viskositas. Viskositas merupakan nilai yang menunjukkan karakteristik reologi suatu cairan $^{(14)}$. Nilai viskositas cenderung meningkat dengan adanya peningkatan konsentrasi kulit pohon kulim. Namun, terjadi penurunan pada konsentrasi 5\%, yang mana mencapai kisaran point yang sama dengan sediaan minyak noaromatik kontrol yaitu $62,2 \%$. Diduga semakin banyak penambahan serbuk kulit pohon kulim maka akan meningkatkan nilai viskositas sediaan minyak aromatik. Karakteristik viskositas yang semakin tinggi memperlihatkan meningkatnya kekentalan suatu bahan. Dengan adanya penambahan bahan solid berupa serbuk kulit pohon kulim pada sediaan minyak maka kekentalan minyak akan meningkat, selain juga menurunkan pergerakan cairan tersebut ${ }^{(15)}$.

\section{Karakteristik Penerimaan Sensori}

Nilai sensori yang diamati meliputi aroma dan warna. Nilai sensori aroma meningkat dengan adanya penambahan kulit pohon kulim pada sediaan minyak. Kulit pohon kulim diketahui memiliki zat volatile metiltiometil ${ }^{(16)}$. Zat ini diduga mampu memproduksi aroma bawang putih dan meningkatkan penerimaan sensori aroma sediaan minyak aromatik. Selain itu, penambahan kulit pohon kulim yang mengandung fenol yang bekerja sebagai antioksidan diduga menghambat produksi asam lemak bebas dan peroksida selama masa inkubasi. Penghambatan produksi asam lemak 
bebas dan peroksida ini mengakibatkan terhambatnya pembentukan komponen volatile bau tengik penyebab bau tengik yang terbentuk melalui proses oksidasi ${ }^{(8)}$. Bau tengik yang terbentuk akan menurunkan tingkat penerimaan sensori aroma. Laju ketengikan oleh potensi antioksidan kulit batang pohon bawang hutan dapat dihambat dan penerimaan terhadap aroma dapat meningkat pada sediaan minyak aromatik terinfusi kulit batang kulim atau pohon bawang dibandingkan sediaan minyak nonaromatik kontrol.

Pada parameter warna, penambahan kulit pohon kulim menurunkan nilai sensori warna sediaan minyak aromatik. Nilai sensori warna semakin menurun dengan adanya peningkatan konsentrasi penambahan kulit pohon kulim, yaitu tertinggi pada konsentrasi $1 \%$, yaitu $5,63 \pm 0,74$ dan terendah adalah pada konsentrasi $6 \%$, yaitu $3,88 \pm 1,46$. Sedangkan sediaan minyak nonaromatik kontrol yang mengandung $0 \%$ konsentrasi kulit pohon memiliki nilai sensori warna yang lebih tinggi dari sediaan minyak aromatik terinfusi kulit pohon kulim, yaitu $6,00 \pm 0,00$.

Penerimaan sensori terhadap warna sediaan minyak memperlihatkan penurunan dengan adanya penambahan kulit pohon kulim sedangkan sediaan minyak nonaromatik kontrol memiliki tingkat penerimaan tertinggi. Hal ini diduga akibat warna kulit pohon kulim yang menyebabkan warna sediaan minyak menjadi berwarna gelap. Semakin banyak jumlah kulit pohon yang ditambahkan maka akan semakin gelap dan keruh. Oleh sebab itu, penampakan minyak dengan penambahan kulit pohon kulim menjadi kurang menarik dan mengakibatkan penurunan nilai penerimaan sensori warna pada sediaan minyak paromatik terinfusi kulit pohon kulim.

\section{KESIMPULAN DAN SARAN}

Nilai asam lemak dan bilangan peroksida cenderung menurun dengan adanya peningkatan kulit batang pohon kulim. Namun, pada parameter reologi, nilai viskositas cenderung meningkat dengan adanya peningkatan konsentrasi kulit pohon kulim. Berdasarkan aspek penerimaan sensori, penambahan kulit batang pohon kulim mengakibatkan adanya peningkatan penerimaan aroma, namun menurunkan penerimaan warna dibandingkan dengan minyak sawit goreng nonaromatik. Dengan demikian, maka kulit batang pohon kulim berpotensi sebagai bahan pembuatan minyak goreng sawit aromatik.

Sebaiknya dilakukan observasi lebih jauh terhadap umur simpan minyak aromatik terinfusi kulit pohon kulim.

\section{DAFTAR PUSTAKA}

1. Lubis AU. Kelapa sawit (Elaeis guineensis Jacq.) di Indonesia. Medan: Pusat Penelitian Kelapa Sawit; 2008.

2. Adams A, Kruma Z, Verhé R, Kimpe ND, Kreicbergs V. Volatile Profiles of Rapeseed Oil Flavored with Basil, Oregano, and Thyme as a Function of Flavoring Conditions. Journal of the American Oil Chemists' Society. 2010;88(2):201-12.

3. Dewi YSK, Mayasari E. Potensi ekstrak daun Sindu (Scorodocarpus borneensis Becc.) sebagai antioksidan alami indogenous Borneo. In Lampung: Universitas Lampung; 2017. p. $700-5$.

4. Abe F, Yamauchi T. Megastigmanes and flavonoids from the leaves of Scorodocarpus borneensis. Phytochemistry. 1993 Jun 3;33(6):1499-501.

5. AOAC. Official methods of Analysis, Vol. II 17th edition. Association of Official Analytical Chemists. Official methods 925.09, 923.03,979.09, 962.09, 4.5.01 and 923.05. Washington (DC); 2000.

6. Meilgaard M, Civille GV, Carr T. Sensory Evaluation Techniques Edition. New York: CRC PRESS; 1999.

7. Rehman Z, Salariya AM, Habib F. Antioxidant activity of ginger extract in sunflower oil. Journal of the science of food and agriculture. 2003;83(7):624-9.

8. Mistry BS, Min DB. Effects of Fatty Acids on the Oxidative Stability of Soybean Oil. Journal of Food Science. 1987;52(3):831-2.

9. Akhtar P, Asghar A, Sheikh A. Effect of proxy radical scavengers on fluorescent light induced oxidation in some edible oils. J Pure Appl Sci. 1985;4:1-7.

10. Sattar A, John M deMan. Effect of Packaging Material on Light Induced Quality Deterioration of Milk. Canadian Institute of Food Science and Technology Journal. 1973 Jul 1;6(3):170-4.

11. Dewi YSK, Purwayantie S, Mayasari E. Bahan Tambahan Alami: Perisa Bawang Putih Dari Pohon Bawang Hutan (Scorodarpus borneensis Becc.). Pontianak: IAIN Pontianak Press; 2018.

12. Kiyomi K, Yasuko S. Formation of lipid peroxides in processed foods in storage and the inhibitory effects of vitamin A and vitamin $\mathrm{E}$ in lipid peroxidation. Kassigeku Kenkyu. 1995;41:91-6.

13. Yanping W, Mourning Z, Yuhang Z, Zhying P. 
Study on effect of different antioxidants on antioxidant properties of oils. Zhongguo Youzhi. 1999;24:37-9.

14. BSN. Cara Uji Viskositas Larutan Karboksimetil Selulosa (CMC). Badan Standarisasi Nasional; 1998.

15. Fadly D, Kusharto CM, Kustiyah L, Suptijah P. Physicochemical Characteristics of Carboxymethyl Chitosan from Silkworm
(Bombyx mori L.) Pupa International Journal of Sciences: Basic and Applied Research (IJSBAR). IJSBAR. 2017;31(1):204-12.

16. Kubota K, Ohhira S, Kobayashi A. Identification and Antimicrobial Activity of the Volatile Flavor Constituents from Scorodocarpus borneensis Becc. Bioscience, Biotechnology, and Biochemistry. 1994 Jan $1 ; 58(4): 644-6$. 